BESt: Journal of Built Environment Studies

P-ISSN: 2746-9077 E-ISSN: 2746-9069

Journal Home Page: https://journal.ugm.ac.id/v3/BEST

\title{
QUALITY OF WALKABILITY IN PEUNAYONG, BANDA ACEH
}

\author{
Adil Mushaithir Darmawan ${ }^{1 *}$, Dwita Hadi Rahmi ${ }^{2}$ \\ 'Department of Architecture and Planning, Faculty of Engineering, Universitas Gadjah Mada, Yogyakarta, Indonesia \\ ${ }^{2}$ Department of Architecture and Planning, Faculty of Engineering, Universitas Gadjah Mada, Yogyakarta, Indonesia
}

\begin{abstract}
Walkability has been introduced as one of the sustainable indicators of urban development. In creating a pedestrian-friendly area, good planning and design of pedestrian facilities are required. The concept of walkability makes an area a pedestrian-friendly environment and this concept can also be used as a measure of the quality of pedestrian paths in urban areas. Peunayong, as a heritage area and trade services in the form of a row of shophouses with Chinatown architecture, has a very strong attraction for walking activities, but on the contrary walking activities are very difficult to do because of various blending activities in the pedestrian path such as trading and parking activities. The difficulty of walking is exacerbated by the condition of the facilities of a pedestrian path that has not been supported, such as the lack of width and unconnected pedestrian path in Peunayong. The analysis methods used scoring analysis and were conducted in 5 segments of Peunayong road with variables of walkability are connected, convenient, comfort and safety, convivial and conspicuous. The results of this study found that 2 segments in Peunayaong have moderate quality while 3 segments have a low quality of walkability.
\end{abstract}

ARTICLE INFO

\section{Keywords:}

Walkability, Pedestrians, Walkable, Peunayong

\section{Introduction}

Walking is a physical activity and mode of transportation owned by everyone (Ackerson, 2005), connecting humans from one place to another (Lantang, 2012) and is an environmentally friendly activity that costs nothing. Walking also can avoid traffic jams and reduce air pollution generated by vehicle transportation (Forsyth, 2015; Forsyth $\&$ Southworth, 2008).

Pedestrian paths and complementary road facilities support walking activities. The existence of pedestrian paths is the main driving force for people to walk from one place to another (Musriati, 2014), including people with disabilities. Pedestrians must walk on the pedestrian path and cross on the crossing that has been provided to protect them from traffic (Ahmad \& Soeparyanto, 2013).

The Regional Spatial Plan of Banda Aceh City in 20092029 states that the Peunayong is a center for trade and services as well as a heritage area. As a trade and service center area, the activities that occur in the Peunayong are very diverse with high intensity. The density of activities in Peunayong causes a high number of vehicle transportations which causes congestion in the area and parking on site, which narrows the space for pedestrians and vehicles. The main problem in Peunayong is pedestrian facilities in the Peunayong area still do not facilitate pedestrians because of the mixing of various activities in one lane, such as circulation, parking, or trading. Pedestrian paths with good conditions and connectivity will be able to create special spaces for pedestrians and people with disabilities that are humane, safe, and comfortable to walk through (Handayani et al., 2018).

Walkability has been introduced as one of the sustainable indicators of urban development. In creating a pedestrian-friendly area, good planning and design of pedestrian facilities are required. The concept of walkability makes an area a pedestrian-friendly environment and this concept can also be used as a measure of the quality of pedestrian paths in urban areas.

With that, the question arises about the quality of walkability in the Peunyaong area. The purpose of this research is to measure the quality of walkability in Peunayong Banda Aceh. 


\section{Literature Review}

Walkability is a state that explains the extent to which an environment can be friendly to pedestrians (Land Transport New Zealand, 2007). Walkability also can be interpreted as a measure of the quality of hospitality of an environment to pedestrians in an area (City of Fort Collins, 2011).

Many health studies say that walking can improve mental and physical health, reduce stress, and increase creativity. The definition of walkable, in addition to encouraging physical activity, is (Forsyth \& Southworth, 2008): 1) close: walkable environments have proximity to the destination; 2) barrier-free: walkable environments can be traversed without obstacles, this includes the elderly, children, disabled, or those wearing heels; 3) safe: a walkable environment is a safe, safe environment against crime and traffic; 4) full of pedestrian infrastructure and destination: a walkable environment is an environment that features comprehensive pedestrian infrastructure such as sidewalks or separate lanes, crossovers, street furniture, and shade trees.

There are 5 things to look out for to create a walkable environment that used in this research:

- Connected

Connected roads provide multiple route options for a variety of activities, resources, services, premises and encourage physical activity (Jackson, 2009). Connectivity comprehensively refers to the straight path as well as the shorter distance to reach the desired goal (Saelens \& Handy, 2008).

- Convenient

The area is easy to understand, bringing a sense of proximity to visual cues and physical direction for pedestrian needs. Wayfinding can be known by pedestrians as well as vehicle users by presenting landmarks, maps, and signs. The right wayfinding system can easily support users to find the environment positively and help visitors to choose the right path (Giles-Corti, Kelty, Zubrick, \& Villanueva, 2009).

\section{- Comfort}

A comfortable place is an environment where the shape and capacity of roads and public spaces are by the pattern of human behavior to bring a sense of comfort and security (A.B. Jacobs, 1993).

- Safety

Pedestrian safety can be considered the most advanced and implicit feature of walkability (Soutworth, 2005). Walking activities are more likely in safer places.

- Convivial

Pedestrian area should be friendly to pedestrians as well as people with disabilities.

- Conspicuous

Pedestrian area should be visible at night as well as street space zoning.

Based on Benjamin Grant, in Getting to Great Places (2013), mentions 6 components of design for walkability, namely:

- Make accession in an area shorter by making blocks smaller or providing access within blocks through alleys, and lanes.

- Land function is directed to support activities, vitality, security, and identity of roads and spaces.

- Place parking in a place that does not interfere with the pedestrian space. Parking should be provided on a multilevel structure because once the parking is done, each driver becomes a pedestrian so that it can enliven public spaces.

- Create humanist spaces with proportion and scale settings that adjust the human scale, which can be done with elements of façade, lighting, signage, and other supporting facilities.

- Pedestrian space is wide and includes elements of trees, lamps, street furniture, and public art. Pedestrian space must also be well connected and form continuity connected with safe deployment.

- Road space can accommodate a variety of modes of transportation and serve as a public facility, commercial space, and green space.

According to Duany Andres (2000), buildings arranged in the area have an effect on roads and context on the series of walkability. The specific elements of an urban morphology that contribute to defining the vitality of urban space are:

- Building orientation and setback:

In a place that is not prioritized to walk, the building is usually less related to the road, either with a wide setback or orientation to the parking lot than the street space. Conversely, the urban contexts with buildings that are oriented and often adjacent to street spaces, therefore walking becomes a high priority.

- Block length:

The development of urban character patterns usually has short blocks with systems that are well connected between pedestrians, roads, and alleys. In contrast to urban areas dominated by vehicles, they usually have large blocks, less complete road connectivity, and usually no alleys. This pattern makes walking longer and therefore people will walk less.

- Building height and street enclosure:

Building is an important part of the urban context that shapes the definition and enclosure of street space, while it is also an important urban design element for making the inner-city space experience a comfortable place for pedestrians. The threshold when pedestrians stop feeling the enclosure is the 1:4 ratio of building height to street width-typical of low-density cities. In denser urban contexts, a high-to-width ratio between $1: 3$ and $1: 2$ creates a suitable enclosure. Walkable environments have a ratio of 1,5 to 2 .

- Building scale and variety:

Help define the context and character of a street and encourage people to walk by providing visual interest to street spaces. The scale and variety of buildings should help define the scale of a walkable environment. ITDP's walkability hierarchy (2018) is described in the pyramid to provide the basis for the development of walkability assessments at the city level (Figure 1): 


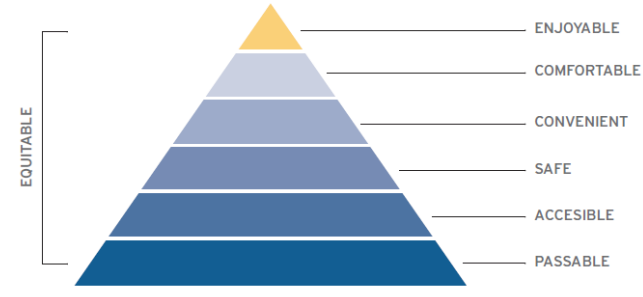

Figure 1. Walkability hierarchy Source: ITDP (2018)

- Passable:

An urban environment that physically allows for walking from one place to another.

- Accessible:

The urban environment in which the destination is within a walkable distance, it can also be accessed by wheelchair users and others who have special needs.

- Safe:

An urban environment that can protect pedestrians from traffic crime, both along and across the street.

- Convenient:

An urban environment prioritizes pedestrians by minimizing the time it takes to walk to a destination, particularly about other modes of transportation such as motor vehicles.

- Comfortable:

An urban environment that minimizes physical discomfort when walking, such as crowding, fatigue, rain, heat, dark, and provides design elements that minimize discomfort.

- Enjoyable:

An urban environment that adds an element of joy for pedestrians through the existence of entertainment, art, and supporting facilities.

The purpose of walkability is to create a pedestrianfriendly environment with road access to destinations that are well connected, comfortable, safe to pass, and no longer dependent on motor vehicles to achieve the destination. The Western Australian Planning Commission (2007) also stressed the need to create a pedestrianfriendly environment, with the following objectives:

- Reduce the dependence on the use of private vehicles and encourage the use of public vehicles by forming compatible city structures.

- Create access that is well connected with various facilities and can be used by all circles, be it pedestrians, cyclists, seniors, and people with disabilities.

- Ensuring the safety of pedestrians by designing the orientation of the building facing the street to increase supervision and activity.

\section{Research Method}

This research area is located in Aceh Province, precisely in Kuta Alam District, Banda Aceh City. The object and location of the research are road corridors that formed Peunayong, namely Jenderal Ahmad Yani Street, Kartini Street, W. R. Supratman Street, Khairil Anwar Street, Sri Ratu Safiatuddin Street, and the road will be referred to as the segment (Table 1).

\begin{tabular}{ll} 
Table 1. Street segment & \\
\hline Segment & Street name \\
\hline Segment 1 & Jenderal Ahmad Yani Street \\
\hline Segment 2 & Kartini Street \\
\hline Segment 3 & W. R. Supratman Street \\
\hline Segment 4 & Khairil Anwar Street \\
\hline Segment 5 & Sri Ratu Safiatuddin Street \\
\hline
\end{tabular}

This research uses the qualitative deductive method by identifying parameter points, variables, and indicators in the research area that correspond to the conditions in the field, then processing the resulting data and analyzing it based on walkability theories.

The approach to this research was done by the theory of walkability as a reference. The focus of this research is to measure walkability in the Peunayong area. The analysis methods used scoring analysis and were conducted in 5 segments of Peunayong streets.

Variables are determined based on derivative parameters on walkability that are adjusted to the context of the research location. The walkability scoring guide is a guideline for walkability assessment in the Peunayong area. This guide is formulated based on variables, parameters, and theories related to looking at the context of data in the Peunayong area (Table 2).

Table 2. Variables and walkability quality scoring guide

\begin{tabular}{|c|c|c|c|c|c|}
\hline Variable & Parameters & Very Low (0) & Low (1) & Moderate (2) & High (3) \\
\hline \multirow[t]{3}{*}{ Connected } & $\begin{array}{l}\text { Pedestrian lane } \\
\text { connectivity }\end{array}$ & $\begin{array}{l}\text { Pedestrian lanes } \\
\text { not available }\end{array}$ & $\begin{array}{l}\text { Pedestrian lanes are } \\
\text { not connected on } \\
\text { either side of the } \\
\text { street }\end{array}$ & $\begin{array}{l}\text { Pedestrian lanes are } \\
\text { connected on one } \\
\text { side of the street }\end{array}$ & $\begin{array}{l}\text { Pedestrian lanes are } \\
\text { connected on both } \\
\text { sides of the street }\end{array}$ \\
\hline & $\begin{array}{l}\text { Conflict in pedestrian } \\
\text { lanes }\end{array}$ & $\begin{array}{l}\text { Pedestrian lanes } \\
\text { not available }\end{array}$ & $\begin{array}{l}\text { Pedestrian lanes have } \\
\text { conflicts with parking } \\
\text { or trading activities } \\
\text { on both sides of the } \\
\text { street }\end{array}$ & $\begin{array}{l}\text { Pedestrian lanes have } \\
\text { conflicts with parking } \\
\text { or trading activities on } \\
\text { one side of the street }\end{array}$ & $\begin{array}{l}\text { Pedestrian lanes have } \\
\text { no conflicts with } \\
\text { parking and trading } \\
\text { activities on both sides } \\
\text { of the street }\end{array}$ \\
\hline & Availability of crossings & $\begin{array}{l}\text { Crossings are not } \\
\text { available }\end{array}$ & $\begin{array}{l}\text { There are crossings, } \\
\text { no signs, and } \\
\text { indecisive limits }\end{array}$ & $\begin{array}{l}\text { There are crossings, } \\
\text { no signs, and firm } \\
\text { limits }\end{array}$ & $\begin{array}{l}\text { There are crossings, } \\
\text { there are signs, and } \\
\text { strict limits }\end{array}$ \\
\hline Convenient & $\begin{array}{l}\text { Availability of signs- } \\
\text { traffic signs, signage, and } \\
\text { information boards }\end{array}$ & $\begin{array}{l}\text { Traffic signs, } \\
\text { signage, and } \\
\text { information } \\
\text { boards are not } \\
\text { available }\end{array}$ & $\begin{array}{l}\text { There are traffic } \\
\text { signs, signage, and } \\
\text { information boards in } \\
\text { some pedestrian } \\
\text { lanes }\end{array}$ & $\begin{array}{l}\text { There are traffic signs, } \\
\text { signage, and } \\
\text { information boards on } \\
\text { one side of the } \\
\text { pedestrian lane }\end{array}$ & $\begin{array}{l}\text { There are traffic signs, } \\
\text { signage, and } \\
\text { information boards on } \\
\text { both sides of the } \\
\text { pedestrian lane }\end{array}$ \\
\hline
\end{tabular}




\begin{tabular}{|c|c|c|c|c|c|}
\hline Variable & Parameters & Very Low (0) & Low (1) & Moderate (2) & High (3) \\
\hline & $\begin{array}{l}\text { Transit distance (bus } \\
\text { stop) to a walkable } \\
\text { destination }\end{array}$ & $\begin{array}{l}\text { Transit distance to } \\
\text { destination }>1 \mathrm{~km}\end{array}$ & $\begin{array}{l}\text { Transit distance to } \\
\text { destination 400-500 } \\
\mathrm{m}\end{array}$ & $\begin{array}{l}\text { Transit distance to } \\
\text { destination 200-300 } \\
\text { m }\end{array}$ & $\begin{array}{l}\text { Transit distance to } \\
\text { destination }<150 \mathrm{~m}\end{array}$ \\
\hline \multirow[t]{6}{*}{$\begin{array}{l}\text { Comfort and } \\
\text { safety }\end{array}$} & $\begin{array}{l}\text { Availability of shade trees } \\
\text { on pedestrian paths }\end{array}$ & $\begin{array}{l}\text { Shade trees are } \\
\text { not available }\end{array}$ & $\begin{array}{l}\text { Shade trees on some } \\
\text { street }\end{array}$ & $\begin{array}{l}\text { There is a shade tree } \\
\text { on one side of the } \\
\text { street }\end{array}$ & $\begin{array}{l}\text { There are shade trees } \\
\text { on both sides of the } \\
\text { street }\end{array}$ \\
\hline & $\begin{array}{l}\text { Availability of street } \\
\text { furniture (seating, trash } \\
\text { cans, handwashing, and } \\
\text { bollards) }\end{array}$ & $\begin{array}{l}\text { Street furniture } \\
\text { (seating, bins, } \\
\text { handwashing, and } \\
\text { bollards) are not } \\
\text { available }\end{array}$ & $\begin{array}{l}\text { There are several } \\
\text { street furniture } \\
\text { (seating, trash cans) } \\
\text { on both sides of the } \\
\text { street }\end{array}$ & $\begin{array}{l}\text { There is street } \\
\text { furniture (seating, } \\
\text { bins, handwashing, } \\
\text { and bollards) on one } \\
\text { side of the street }\end{array}$ & $\begin{array}{l}\text { There are street } \\
\text { furniture (seating, bins, } \\
\text { handwashing, and } \\
\text { bollards) on both sides } \\
\text { of the street }\end{array}$ \\
\hline & Width of pedestrian lanes & $\begin{array}{l}\text { Pedestrian lanes } \\
\text { not available }\end{array}$ & $\begin{array}{l}\text { It has a width of }<1 \\
m\end{array}$ & $\begin{array}{l}\text { It has a width of }<1,2 \\
m\end{array}$ & It has a width of $>1,5 \mathrm{~m}$ \\
\hline & $\begin{array}{l}\text { Material condition of } \\
\text { pedestrian lanes }\end{array}$ & $\begin{array}{l}\text { Pedestrian lanes } \\
\text { not available }\end{array}$ & $\begin{array}{l}\text { Material conditions } \\
\text { are bad, damaged, } \\
\text { and perforated in } \\
\text { some pedestrian lane }\end{array}$ & $\begin{array}{l}\text { Material condition is } \\
\text { good, not damaged, } \\
\text { not perforated on one } \\
\text { side of the pedestrian } \\
\text { lane }\end{array}$ & $\begin{array}{l}\text { The condition of the } \\
\text { material is good, } \\
\text { undamaged, not } \\
\text { perforated on both } \\
\text { sides of the pedestrian } \\
\text { lane }\end{array}$ \\
\hline & $\begin{array}{l}\text { Mix used as transparent } \\
\text { element (eyes on the } \\
\text { street) }\end{array}$ & $\begin{array}{l}\text { Mix used not } \\
\text { available }\end{array}$ & $\begin{array}{l}\text { There is a mix-used } \\
\text { building on some } \\
\text { street }\end{array}$ & $\begin{array}{l}\text { There is a mix-used } \\
\text { building on one side } \\
\text { of the street }\end{array}$ & $\begin{array}{l}\text { There is a mix-used } \\
\text { building on both sides } \\
\text { of the street }\end{array}$ \\
\hline & Street vendor Availability & $\begin{array}{l}\text { Street vendors are } \\
\text { not available }\end{array}$ & $\begin{array}{l}\text { There are street } \\
\text { vendors on some } \\
\text { streets and inhibit } \\
\text { walking activities }\end{array}$ & $\begin{array}{l}\text { There is a vendor } \\
\text { street on one side of } \\
\text { the street and does } \\
\text { not hamper walking } \\
\text { activities }\end{array}$ & $\begin{array}{l}\text { There are street } \\
\text { vendors on both sides } \\
\text { of the street and do not } \\
\text { hinder walking activities }\end{array}$ \\
\hline \multirow[t]{4}{*}{ Convivial } & $\begin{array}{l}\text { Spatial enclosure and } \\
\text { Humanscale }\end{array}$ & $\begin{array}{l}\text { Loss of } \\
\text { enclosure/space } \\
\text { loss of closure and } \\
\text { influence of space } \\
\text { is not felt }\end{array}$ & $\begin{array}{l}\text { Minimum enclosures } \\
\text { begin to lose closure } \\
\text { and the influence of } \\
\text { space begins to be } \\
\text { felt }\end{array}$ & $\begin{array}{l}\text { Full enclosure and feel } \\
\text { balanced }\end{array}$ & $\begin{array}{l}\text { Threshold of } \\
\text { enclosure/last } \\
\text { boundary of space and } \\
\text { space closure feels } \\
\text { rather large }\end{array}$ \\
\hline & Vehicle speed control & $\begin{array}{l}\text { Speed control is } \\
\text { not available }\end{array}$ & $\begin{array}{l}\text { There is a narrow } \\
\text { street and sign speed } \\
\text { limit of the vehicle }\end{array}$ & $\begin{array}{l}\text { There are speed } \\
\text { bumps, vehicle speed } \\
\text { limit signs, and } \\
\text { narrow street }\end{array}$ & $\begin{array}{l}\text { There are raised } \\
\text { crossings, speed } \\
\text { bumps, vehicle speed } \\
\text { limit signs, and narrow } \\
\text { roads }\end{array}$ \\
\hline & $\begin{array}{l}\text { Availability of ramps on } \\
\text { pedestrian paths }\end{array}$ & $\begin{array}{l}\text { Ramp not } \\
\text { available }\end{array}$ & $\begin{array}{l}\text { There is a ramp on } \\
\text { part of the street }\end{array}$ & $\begin{array}{l}\text { There is a ramp on } \\
\text { one side of the street }\end{array}$ & $\begin{array}{l}\text { There are ramps on } \\
\text { both sides of the street }\end{array}$ \\
\hline & $\begin{array}{l}\text { Availability of guiding } \\
\text { blocks on pedestrian } \\
\text { paths }\end{array}$ & $\begin{array}{l}\text { Guiding block not } \\
\text { available }\end{array}$ & $\begin{array}{l}\text { There are guiding } \\
\text { blocks on some } \\
\text { street }\end{array}$ & $\begin{array}{l}\text { There is a guiding } \\
\text { block on one side of } \\
\text { the street }\end{array}$ & $\begin{array}{l}\text { There are guiding } \\
\text { blocks on both sides of } \\
\text { the street }\end{array}$ \\
\hline \multirow[t]{4}{*}{ Conspicuous } & $\begin{array}{l}\text { Division modes of } \\
\text { transportation }\end{array}$ & $\begin{array}{l}\text { There are no } \\
\text { division modes of } \\
\text { transportation }\end{array}$ & $\begin{array}{l}\text { There is a division of } \\
\text { modes of } \\
\text { transportation private } \\
\text { vehicle and parking }\end{array}$ & $\begin{array}{l}\text { There is a division of } \\
\text { modes of } \\
\text { transportation such as } \\
\text { pedestrians, private } \\
\text { vehicles, and parking }\end{array}$ & $\begin{array}{l}\text { There is a division of } \\
\text { modes of } \\
\text { transportation such as } \\
\text { transit (bus), bicycles, } \\
\text { pedestrians, private } \\
\text { vehicles, and parking }\end{array}$ \\
\hline & Parking on street & $\begin{array}{l}\text { There is parking } \\
\text { on-street on both } \\
\text { sides of the lane } \\
\text { with } 45 \text { degrees }\end{array}$ & $\begin{array}{l}\text { There is parking on- } \\
\text { street on one side of } \\
\text { the street with } 45 \\
\text { degrees }\end{array}$ & $\begin{array}{l}\text { There is parking on- } \\
\text { street on one side of } \\
\text { the road with } 0 \\
\text { degree }\end{array}$ & $\begin{array}{l}\text { There is parking on } \\
\text { some streets with } 0 \\
\text { degree }\end{array}$ \\
\hline & $\begin{array}{l}\text { Parking off the street } \\
\text { (vacant lots, parking, } \\
\text { basement buildings, and } \\
\text { parking buildings) }\end{array}$ & $\begin{array}{l}\text { There is no off- } \\
\text { street parking } \\
\text { along the lanes }\end{array}$ & $\begin{array}{l}\text { Off-street parking is } \\
\text { done in the building's } \\
\text { existing setbacks }\end{array}$ & $\begin{array}{l}\text { There is off-street } \\
\text { parking in the form of } \\
\text { vacant land used for } \\
\text { parking and a parking } \\
\text { building }\end{array}$ & $\begin{array}{l}\text { There is off-street } \\
\text { parking in the form of } \\
\text { vacant land used for } \\
\text { parking, basement } \\
\text { buildings, and parking } \\
\text { buildings }\end{array}$ \\
\hline & Streetlight & $\begin{array}{l}\text { Street lights are } \\
\text { not available }\end{array}$ & $\begin{array}{l}\text { Street lights are } \\
\text { available on some } \\
\text { streets }\end{array}$ & $\begin{array}{l}\text { Street lights are } \\
\text { available on one side } \\
\text { of the street }\end{array}$ & $\begin{array}{l}\text { Street lights are } \\
\text { available on both sides } \\
\text { of the street }\end{array}$ \\
\hline
\end{tabular}




\section{Results and Discussions}

The segment analysis is conducted based on variables and standards in the form of scoring assessment of walkability qualities with variables: connected, convenient, comfort and safety, convivial and conspicuous. Here are the indicators on how to assess the quality of walkability in the Peunayong area (Table 3):

\begin{tabular}{cll} 
Table 3. Walkability quality assessment indicator & \\
\hline Score & Assessment indicator & Description \\
\hline 0 & Parameters not available in the & Walkability is \\
& segment/very low parameter quality & very low \\
\hline 1 & $\begin{array}{l}\text { Parameters available but only partially } \\
\text { in the road segment/low parameter } \\
\text { quality/incomplete parameters }\end{array}$ & $\begin{array}{l}\text { Low } \\
\text { walkability }\end{array}$ \\
\hline 2 & $\begin{array}{l}\text { Parameters are available and only exist } \\
\text { on one side of the segment/moderate } \\
\text { parameter quality/partial complete }\end{array}$ & Moderate \\
& walkability \\
\hline 3 & $\begin{array}{l}\text { Parameters are available and are on } \\
\text { both sides of the road segment/high } \\
\text { parameter quality/complete } \\
\text { parameters }\end{array}$ & High \\
& walkability \\
\end{tabular}

The assessment indicator is divided by 4 , if the parameter is not available in the segment or the quality of the parameter is very low, then the value is 0 , which means very low walkability. When parameters are available but only available on some segments or low parameter quality or incomplete parameters, the value is 1 which means low walkability. However, if the parameter is available and only exists on one side of the segment or the quality of the parameter is moderate or partially complete, then the value is 2 which means moderate walkability. Lastly, if parameters are available and are on either side of the segment or high parameter quality or complete parameter, then the value of 3 means high walkability. The results of Peunayong's walkability quality assessment are shown in Figure 2.

The results of walkability assessment per parameter for each segment are shown in Figure 2. There are several parameters with very low quality, namely the availability of crossings, vehicle speed control, availability of ramps and guiding blocks, and parking on and off the street. For low quality, there is the availability of shade trees, availability of street furniture, the width of pedestrian lanes, and the availability of street lights. For moderate-quality, there is pedestrian lane connectivity, conflict in the pedestrian lane, ease of transit distance, the material condition of pedestrian lanes, street vendors, street enclosure hospitality, and transportation mode. High-quality parameters there are 2, namely ease of access to information and mix used functions. Overall the walkability quality of the Peunayong area is dominated by very low and moderate values. While the results of walkability assessment based on segments are as follows (Table 4 and Figure 3).

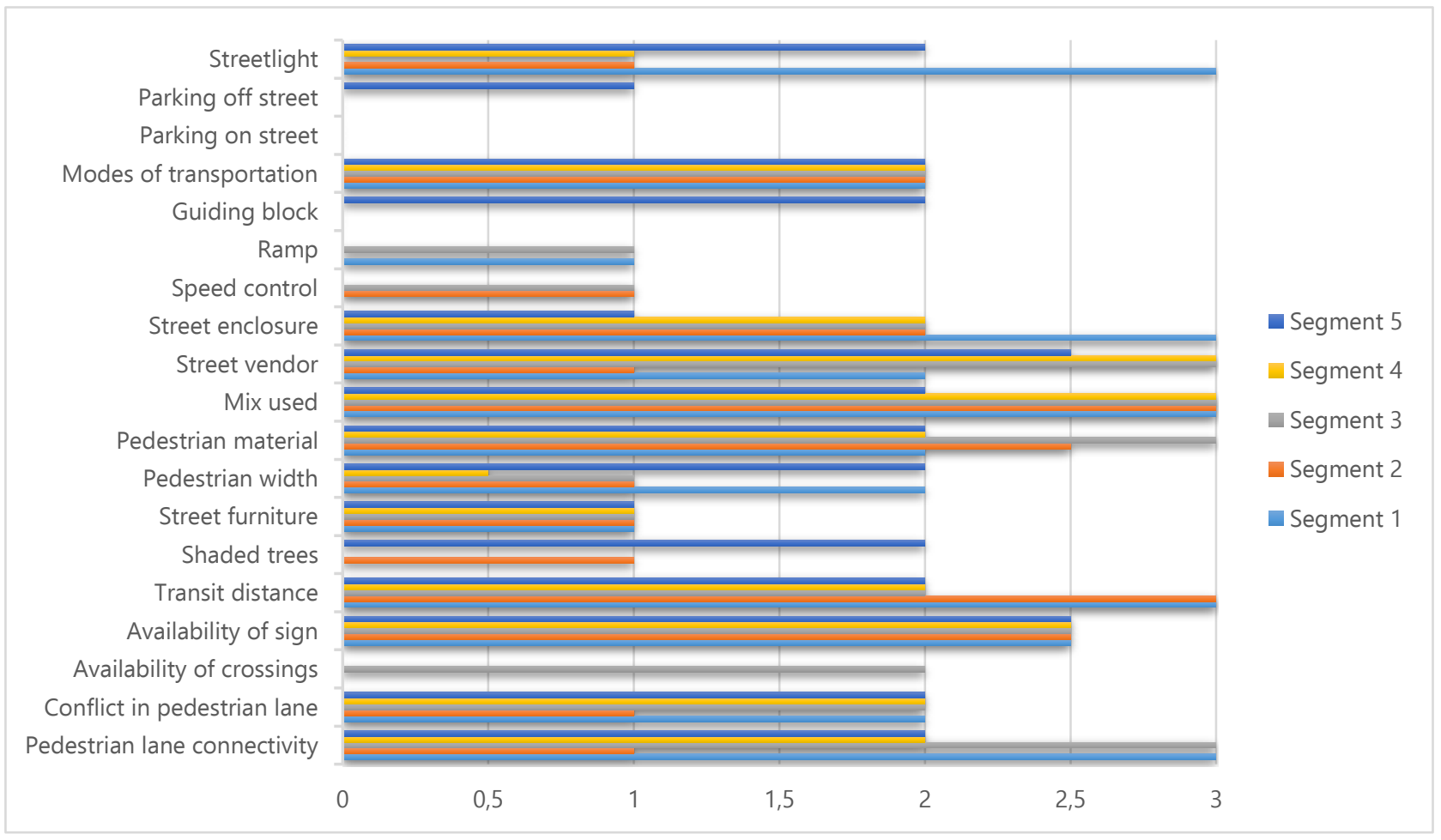

Figure 2. Recapitulation of scoring walkability results 


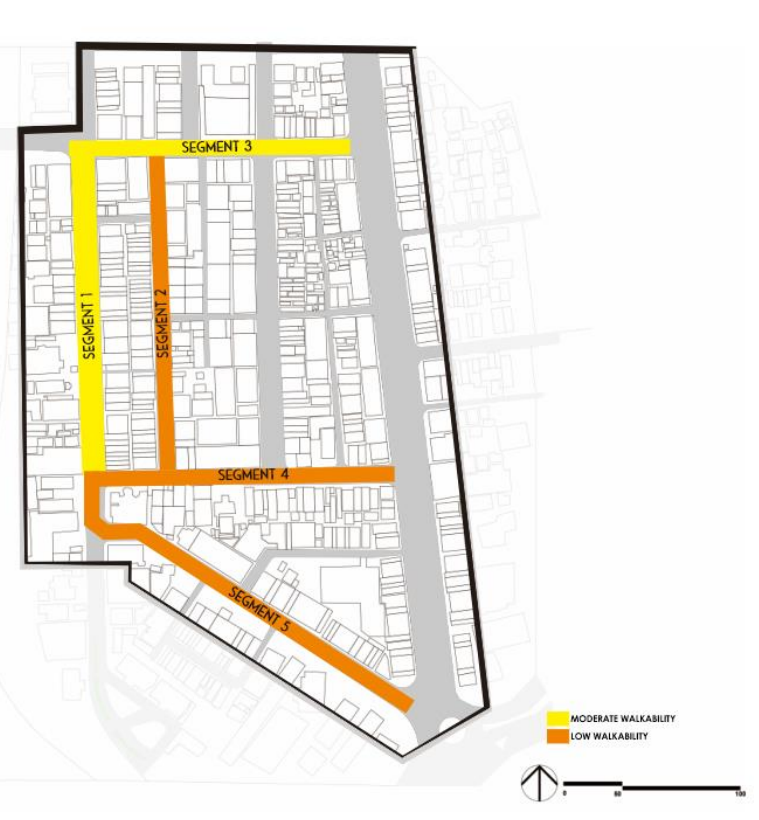

Figure 3. Mapping the results of walkability scoring

Table 4. Walkability quality assessment indicator

\begin{tabular}{lcl}
\hline Segment & Total Score & Description \\
\hline Segment 1 & 1,64 & Moderate walkability \\
\hline Segment 2 & 1,28 & Low walkability \\
\hline Segment 3 & 1,57 & Moderate walkability \\
\hline Segment 4 & 1,27 & Low walkability \\
\hline Segment 5 & 1,49 & Low walkability \\
\hline
\end{tabular}

Based on scoring results regarding the quality of walkability in the Peunayong area, 3 segments get low scores, namely segments 2,4 , and 5 , while 2 segments get moderate scores, namely 1 and 3 . The lowest walkability quality in segment 4 with a score of 1,27 , then segment 2 with a score of 1,28 . The third-lowest score in segment 5 was 1,49 , then segment 3 with a score of 1,57 . The highest score is in segment 1 , which is 1,64 . There is no segment in the Peunayong area that is high quality of walkability.

After getting the quality of walkability in general then the quality is adjusted to the role of ITDP, there are 6 ranking categories, namely passable, accessible, safe, convenient, comfortable, and enjoyable. Here are the results of the ranking (Table 5):

Table 5. Walkability quality categories based on ITDP

\begin{tabular}{|c|c|c|}
\hline Ranking & Indicator & Peunayong \\
\hline Passable & $\begin{array}{l}\text { It is possible to walk } \\
\text { from one place to } \\
\text { another }\end{array}$ & $\begin{array}{l}\text { Peunayong makes it } \\
\text { possible to walk from } \\
\text { one place to another }\end{array}$ \\
\hline \multirow[t]{2}{*}{ Accessible } & $\begin{array}{l}\text { The destination inside is } \\
\text { within a walkable } \\
\text { distance }\end{array}$ & $\begin{array}{l}\text { Destinations in } \\
\text { Peunayong are within } \\
\text { walking distance }\end{array}$ \\
\hline & $\begin{array}{l}\text { It can be accessed by } \\
\text { wheelchair users and } \\
\text { others who have special } \\
\text { needs }\end{array}$ & $\begin{array}{l}\text { Peunayong is not } \\
\text { accessible to } \\
\text { wheelchair users and } \\
\text { people with special } \\
\text { needs }\end{array}$ \\
\hline Safe & $\begin{array}{l}\text { Can protect pedestrians } \\
\text { from traffic crime, both } \\
\text { along and across the } \\
\text { road }\end{array}$ & $\begin{array}{l}\text { Peunayong has not } \\
\text { been able to protect } \\
\text { pedestrians from } \\
\text { traffic crime }\end{array}$ \\
\hline Comfortable & $\begin{array}{l}\text { Prioritize pedestrians by } \\
\text { minimizing the time it } \\
\text { takes to walk to a }\end{array}$ & $\begin{array}{l}\text { Peunayong still has } \\
\text { not prioritized } \\
\text { pedestrians, is still }\end{array}$ \\
\hline
\end{tabular}

\begin{tabular}{lll}
\hline & $\begin{array}{l}\text { destination, particularly } \\
\text { about other modes of } \\
\text { transportation such as } \\
\text { motor vehicles }\end{array}$ & $\begin{array}{l}\text { oriented to motor } \\
\text { vehicles to achieve } \\
\text { the destination }\end{array}$ \\
\hline Enjoyable & $\begin{array}{l}\text { Add an element of joy } \\
\text { for pedestrians through } \\
\text { the presence of } \\
\text { entertainment, art, and } \\
\text { support facilities }\end{array}$ & $\begin{array}{l}\text { Peunayong does not } \\
\text { yet have an element } \\
\text { of joy for pedestrians }\end{array}$ \\
\hline
\end{tabular}

Based on the table above, the Peunayong area only meets the criteria or indicators of passable, meaning that the Peunayong pedestrian path is included in the lowest or minimum ranking based on ITDP, which is passable.

\section{Conclusion}

Based on the results of research that has been done, Segment 1 Jenderal Ahmad Yani Street has moderate walkability quality that lacks quality, especially in the convivial part. Segment 1 is not friendly for pedestrians, especially for pedestrians who have special needs. In Segment 2, Kartini Street has a low category of walkability quality, especially in the connected part that causes pedestrian lanes in segment 2 can not connect properly, then convivial, which means segment 2 is not yet friendly to pedestrians, especially for the disabled ones, and conspicuous related to parking spaces and street lights for lighting at night. Segment 3, W. R. Supratman Street has moderate walkability quality that lacks quality, especially in the conspicuous section related to parking spaces and street lights for lighting at night and convivial, so segment 3 is not friendly for pedestrians, especially for disabled people. Segment 4, Khairil Anwar Street has low walkability quality. The low quality of walkability in segment 4 is equal to the low quality in segment 2 , namely convivial, which means that segment 4 has not been friendly to pedestrians, especially for the disabled ones, and conspicuous related to parking spaces and street lights for lighting at night. Segment 5, Sri Ratu Safiatuddin Street has a walkability quality that falls into the low category. The low quality in this segment is due to the low-quality value on 3 variables, namely connected which means that segment 5 of pedestrian lanes in segment 5 is not connected, convivial (friendliness) which means segment 5 is not friendly to pedestrians, especially disabled people.

Although the quality of walkability is low and moderate, all segments in the Peunayong area have high walkability potential. The increase in potential can be done with improvements in several parameters such as adding and improving pedestrian lanes, sharing modes of transportation, adding access to information, shade trees, and street furniture, and providing access for disabilities. However, some parameters do not have the potential for improvements, such as street enclosure and parking offstreet. These parameters do not have the potential to be improved because they relate to land carrying capacity and existing conditions that are difficult to change, such as building height and building setbacks.

Quality of walkability research has limitations that only look at the physical aspects of street space in the Peunayong area. It is less complete if walkability research does not discuss the deeper aspects of enclosures, namely the facade of the building that forms the aesthetics of the 
area, especially Peunayong as a heritage area that has a Chinatown architectural façade. Therefore this quality of walkability research has not been completed and can be continued to examine the aesthetics of the building façade of the area to get comprehensive walkability results.

\section{References}

Ackerson, K. J. (2005). A GIS Approach to Evaluating Streetscape and Neighborhood Walkability. Oregon: University of Oregon.

Agustin, I. W. (2017). Penerapan Konsep Walkability di Kawasan Alun-Alun Kota Malang. Jurnal Pengembangan Kota, 5(1), 45.

Ahmad, S. N., Soeparyanto, T. S. (2013). Studi Perilaku Pejalan kaki dan Penyebrangan Jalan pada Kawasan Fakultas Pertanian Universitas Halu Oleo. Stabilita, 275-290.

Austroads. (2009). Guide to Road Design Part 6A: Pedestrian and Cyclist Paths. Austorads Incorporated.

Basuki, K. H. (1992). Studi Kasus: Penataan Koridor Perdagangan di Kawasan Teluk Betung Bandar Lampung. Jurnal Rekayasa, 19(1).

Cahya, D., and Metalia, R. (2011). Konsep Perencanaan Kawasan Perdagangan Koridor Jalan Sa. Tirtayasa, Kota Serang dengan Pendekatan Pedestrianisasi (Memanusiakan Pejalan Kaki). Planesa, 2(1), 1-9.

Cambra, P. (2012). Pedestrian Accessibility and Attractiveness Indicators for Walkability Assessment. Engineering and Architecture, 1-10.

Choi, E. (2012). Walkability as an Urban Design Problem: Understanding the Activity of Walking in The Urban Design Environment. Architecture and the Built Environment, Sweden.

City of Fort Collin. (2011). Fort Collins Pedestrian Plan.

Department for Transport. (2011). Walkability Audit Tool (Assessment Tool). Workplace Health \& Safety, 63(9), 420.

Development, C. U. (2019). Banda Aceh, Indonesia Consolidated Urban Development Program for Krueng Aceh River. May.

Dirjen Bina Marga. (1999). Pedoman Perencanaan Jalur Pejalan Kaki pada Jalan Umum. No.032/T/BM/1999. Jakarta.

Duany, Andres. (2000). A Theory of Urbanism.

Ewing, R. and Handy, S. (2009). Measuring The Unmeasurable. Urban Design Qualities Related to Walkability. Journal of Urban Design, 14(1), 65-84.

Fahrizal, E., Aulia, T. B., and Safwan, S. (2018). Evaluasi Komponen Fisik Bangunan Pasar Sayur dan Buah Peunayong Kota Banda Aceh terhadap Upaya Relokasi. Jurnal Arsip Rekayasa Sipil dan Perancanaan, 1(3), B016-B022.

Farnian, S. (2014). Reclaiming Pedestrian-Oriented Places to Increase Walkability in City Center the Case of Yuksel Street, Ankara. Urban Design in City and Regional Planning Department, Middle East Technical University.

Forsyth, A. N. N., and Southworth, M. (2008). Cities AfootPedestrians, Walkability and Urban Design. Journal of Urban Design, 13(1), 1-3.

Forsyth, Ann. (2015). What is a walkable place? The walkability debate in urban design. Urban Design International, 20(4), 274292.

Giles-Corti, B., Kelty, S. F., Zubrick, S. R., Villanueva, K. P. (2009). Encouraging walking for transport and physical activity in children and adolescents. Sports medicine, 39(12), 995-1009.

Gori, S., Nigro, M., and Petreli, M. (2014). Walkability Indicators for Pedestrian-Friendly Design. Transportation Research Record, 2464(1), 38-45.

Grant, B. (2013). Getting to Great Places. SPUR Report.

Handayani, S., Irwansyah, M., and Isya, M. (2018). Tinjauan Sarana dan Prasarana Jalur Pedestrian di Kawasan Peunayong, Banda
Aceh. Jurnal Arsip Rekayasa Sipil Dan Perencanaan, 1(3), 171179.

Iswanto, D. (2006). Pengaruh Elemen-elemen Pelengkap Jalur Pedestrian terhadap Kenyamanan Pejalan Kaki (Studi Kasus Penggal Jalan Pandanaran Dimulai dari Jalan Randusari hingga Kawasan Tugu Muda). Enclosure, 5(1), 21-29.

ITDP. (n.d). Tools for a Walkable City.

Joshua, A. and Mandai, O. H. (2016). Kajian Perilaku Berjalan Kaki pada Kawasan Lapangan Merdeka di Kota Medan.

Jackson, G. (2009). Denver's first pedestrian priority zone.

Jacobs, A. B. (1993). Making great streets. Great Streets, 269-292.

Khder, H. M., Mousavi, S. M., and Khan, T. H. (2016). Impact of Street's Physical Element on Walkability: A Case of Mawlawi Street in Sulaymaniyah, Iraq. International Journal of Built Environment and Sustainability, 3(1), 18-26.

Lantang, E. T. (2012). Fasilitas Pejalan Kaki yang Ramah Gender di Kota Makassar. Universitas Hassanuddin.

Lefebre-Ropars, G. and Morency, C. (2008). Walkability: Which Measure to Choose, Where to Measure it, and How? Transportation Research Record: Journal of The Transportation Research Board, 2672(35), 139-150.

Lo, R. H. (2009). Walkability: What is it? Journal of Urbanism, 2(2), 145-166.

Mangkususumo, R. S. R. (2012). Pengaruh Kualitas Rancang Kota terhadap Keinginan untuk Berjalan Kaki pada Kawasan Wisata Pantai Kuta-Bali. Temu IImiah IPLBI 2012, 25-28.

Mandasari, F. and Nurini. (2013). Analisis Karakter Kampung Pecinan di Kawasan Perdagangan dan Jasa Peunayong Pusat Kota Banda Aceh. Jurnal Ruang, 7(1).

Mokodongan, E. F. and Tallei, V. R. (2006). Prinsip Desain Koridor Komersial di Kawasan Kota Tua Gorontalo. Temu I/miah IPLBI 2016, 1, 1-8.

Musriati, L. A. (2014). Penataan Jalur Pejalan Kaki di Kawasan Pusat Kota Malang berdasarkan Kriteria Safety, Convenience, Comfort dan Attractiveness. Universitas Brawijaya, Malang.

Nunes, D. V. and Vale, D. S. (2015). Physical Characteristics that Influence Urban Design Qualities of Livable and Walkable Urban Places: Lesson From Portuguese Cities. 52nd International Making Cities Livable Conference, September, 1-18.

Nurgianto. (2013). Konsep Perancangan dalam Meningkatkan Kualitas Lingkungan Fisik Kawasan Perdagangan dan Jasa Jenderal Surdirman Kota Salatiga. Jurnal Pembangunan Wilayah \& Kota, Biro Penerbit Planologi Undip, 9(1).

NZ Transport Agency. (2009). Pedestrian Planning and Design Guide. New Zealand Government.

Paramastri, S. and Pamungkas, T. (2008). Walkability pada Jalur Pedestrian di Area Kampus Universitas Negeri Malang. Jurnal Mahasiswa Jurusan Arsitektur Universitas Brawijaya, 6(3), 1-9.

Pemerintah Kota Banda Aceh. (2017). Rencana Pembangunan Jangka Menegah Daerah (RPJMD) Kota Banda Aceh 2017-2022.

Peraturan Menteri Pekerjaan Umum Nomor: 03/PRT/M/2014. (2014). Pedoman Perencanaan, Penyediaan, dan Pemanfaatan Prasarana dan Sarana Jaringan Pejalan Kaki di Kawasan Perkotaan.

Pradigna, G. and Widayani, P. (2019). Kajian Penilaian Tingkat Walkability Menggunakan Walkability Index di Sebagian Kota Yogyakarta. Jurnal Bumi Indonesia, 8(4).

Putra, L. N. (2019). Perancangan Sign System di Kawasan Kampung Adat "Cireundeu". 1-47.

Saelens, B. E., Handy, S. L. (2008). Built environment correlates of walking: A review. Medicine and science in sports and exercise, $40(7$ Suppl), S550. 
Sepe, M. (2009). PlaceMaker Method: Planning "Walkability" by Mapping Place Identity. Journal of Urban Design, 14(4), 463487.

Singh, R. (2016). Factors Affecting Walkability of Neighborhoods. Procedia-Social and Behavioral Sciences, 216 (October 2015), 643-654.

Southworth, M. (2005). Designing the walkable city. Journal of urban planning and development, 131(4), 246-257.

Surya, I. R. and Sudaryatno, S. (2017). Pemanfaatan Indeks Walkability (Kenyamanan Pejalan Kaki) dan Hubungannya dengan Kualitas Jalur Pedestrian di Kawasan Wisata Malioboro Yogyakarta. Jurnal Bumi Indonesia, 6(3), 1-6.

Tanan, N., Wibowo, S. S., and Tinumbia, N. (2017). Pengukuran Walkability Index pada Ruas Jalan di Kawasan Perkantoran. Jurnal Jalan-Jembatan, 34(2), 115-127.

Wardhani, D. K., Antariksa, and Sari, N. I. (2011). Peunayong Chinatown Banda Aceh Post-Earthquake and Tsunami as Cultural Heritage District. Journal of Basic and Applied Scientific Research, 1(4), 275-282.

Western Australian Planning Commission. (2007). Liveable Neighbourhood: A Western Australian Government Sustainable Cities Initiatives. Perth: Western Australian Planning Commission.

Winarso, H., and Dewi, C. (2005). Urban Heritage Conservation in Aceh, Indonesia: Conserving Peunayong for Tourism. ASEAN Journal on Hospitality and Tourism, 9, 15-28.

Zahra, An Nisa and Syaodih, Ernady. (2010). Kajian Prinsip Penataan Koridor Jalan Sultan Agung di Kota Bekasi. 